\title{
A MAGYARORSZÁGI TEJTERMELÓ ÉS TEJFELDOLGOZÓ VÁLLALKOZÁSOK IKT HASZNÁLATÁNAK ELEMZÉSE
}

\author{
26 \\ ANALYSING ICT USAGE OF HUNGARIAN MILK PRODUCERS AND MILK PROCESSORS
}

Botos, Szilvia
SZILÁGY, Róbert
VÁRALLYA, László
FELFÖLDI, János

Debreceni Egyetem, Gazdaságtudományi Kar, Alkalmazott Informatika és Logisztika Intézet (University of Debrecen, Faculty of Economics and Business, Institute of Applied Informatics and Logistics)

H-4032 Debrecen, Böszörményi út 138 .

E-mail: botos.szilvia@econ.unideb.hu

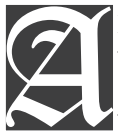

Milk production and processing is one of the main agrofood sectors in Hungary. In 2016, the number of enterprises operating in milk production and milk processing sector was 741 and 8o, respectively. Advanced information systems enable us to attain more and thorough data on their operation and performance and the analysis of these data is crucial for the evaluation of their situation in the sector. These data sets are important for monitoring and assessing the performance of different sectors. Hungarian Central Statistical Office provides multidimensional databases, while financial and additional information of more than half of the operating enterprises are available in EMIS database. As a complementary database, Institute of Applied Informatics and Logistics has prepared a questionnaire for survey the ICT (Information and Communication Technologies) usage characteristics of enterprises operating in the agro-food supply chain (producers and processors). The survey was conducted in the fourth quarter of 2017 and using structured questionnaire and responses are recorded by a market research company contacting the leaders or a management member of the enterprises. The sample has been selected by stratified sampling based on statistics of Hungarian Central Statistical Office (HCSO). Enterprise size based on staff employed and region at NUTS-2 level were the basis of sampling. Data set contains data about 500 enterprises operating in sectors related to agriculture and food industry ( 355 are operating in the production part, 145 in the processing part of the chain). 38 enterprises operating in the milk sector from the whole sample ( 28 belong to milk production and 10 to milk processing sector). The main objective of current article is to determine the difference between food producers and food processors, and separately between milk producers and milk processors regarding their evaluation of ICT devices in their partnerships an the internet-based solutions for certain business activities. Respondents assessed the importance of ICT on 5-point Likert scale relating to four business activities (communication; data storage and exchange, preparing documents; logistics; marketing). To determine the difference, two-sample t-test has been applied. Our results show significant difference only in the case of bulk sample, between food producers and food processors, in the evaluation of ICT devices for marketing purposes. The mean of scores given by food processors was significantly higher (Sig. (2-tailed) $=\mathbf{0 , 0 1 3 4}$ and $t$-value $=-\mathbf{2}, 4829$ ). There is no siginificant difference between milk producers and milk processors, however, the means of scores given by the latter for the importance of ICT tools were higher in the case of each four business activites. 


\section{BEVEZETÉS - INTRODUCTION}

A vállalati elemzéseket tekintve az utóbbi évtizedekben a pénzügyi eredményesség mellett a fenntarthatóság is előtérbe került. Az Információs és Kommunikációs Technológiák (IKT) alkalmazásának mindkét aspektusban vannak előnyei. Az IKT olyan hajtóerőt jelent, amely hozzájárul a fenntartható és versenyképes gazdaság kialakulásához (GOUVEA et al., 2018). A tejipari ellátási láncot vizsgálva is számos publikáció jelent meg arról, hogy az IKT milyen előnyöket jelent a lánc szereplőinek és az ellátási lánc egészének müködésére. Az elmúlt évtizedben számos empirikus elemzés és esettanulmány jelent meg arról, hogy az információs rendszerek milyen előnyöket jelentenek a decentralizált ellátási láncokban és hogy az ellátási láncok szereplői közötti információmegosztással kapcsolatos jellemzői milyen hatással vannak a múködésre és a teljesítményre. VIET és szerzőtársai (2018) az információellátási láncokban betöltött szerepével foglalkozó szakirodalom, összesen 141 cikk fóbb megállapításait foglalják össze. A szakirodalom többsége egyetért abban, hogy az információsrendszer-gyakorlatok és az információmegosztás minősége kulcsfontosságú szerepet játszik az ellátási láncok teljesítményében (DOMINGUEZ et al., 2018). Példaként, DOMINGUEZ és szerzőtársai (2018) cikkükben hivatkoznak egy nemrégiben elkészült felmérés eredményére, ami szerint a kínai vállalkozások 61 százaléka úgy tartja, hogy az információs rendszer elengedhetetlen az üzleti sikerhez (BIAN et al., 2016).

Habár számos publikációban közöltek eredményeket arról, hogy a különböző ellátási láncok esetében milyen hatása van az információs rendszerek alkalmazásának, az információmegosztási technikáknak és az IKT alkalmazás színvonalának, még mindig van igény további kutatásokra. Egyrészt azért, mert annak ellenére, hogy az információs rendszerek alkalmazása jelentős előnyökkel jár, sok esetben a vállalkozások nem képesek kihasználni azokat (FAWCETT et al., 2011), másrészt a vállalatok számára fontos, hogy pénzügyileg is megalapozott legyen egy információs rendszer, vagy hatékony ellátási lánc gyakorlat bevezetése (ZHOU et al., 2014), amihez szükséges válla- lati elemzések készítése. TEUNTER és szerzőtársai (2018) következtetése szerint hiány van empirikus kutatásokból és esettanulmányokból, pedig ezek szükségesek ahhoz, hogy az elméletben már leírt előnyöket alátámasszák.

DOMINGUEZ és szerzőtársai (2018) szintén továbbfejlesztésre javasolják kutatásukat a bevont szereplők (esetükben kereskedők) számának skálázásával, illetve érdekesnek tartják annak vizsgálatát, hogy az ellátási lánc beszállítói (upstream) oldalán lévő szereplők múködése hogyan hat a kereskedők közötti információmegosztásra.

VACHON és KLASSEN (2006) cikkükben a fenntartható fejlődéssel kapcsolatban állapítják meg, hogy a vállalati vezetők egyre inkább rá vannak kényszerülve, hogy a társadalmi és környezetvédelmi kérdésekkel is foglalkozzanak, nem maguk, mint inkább az ellátási láncban résztvevő partnereik miatt. SANTIS és szerzőtársai (2016) brazil vállalkozások adatain végeztek elemzést és számos szakirodalmat feldolgoztak a fenntarthatóság és a pénzügyi teljesítmény közötti kapcsolat meghatározásához és eredményeik azt mutatták, hogy a kapcsolat nem egyértelmú és inkább a gazdasági szektor meghatározó a pénzügyi teljesítményt illetően és nem a fenntarthatóság érdekében végzett beruházások. Mégis, a fenntarthatóság a lánc egészét vizsgálva igen fontos szempont.

KIRILOVA és VAKLIEVA-BANCHEVA (2017) szerint a fenntarthatóság növeléséhez az ún. Zöld Ellátási Lánc Menedzsment (Green Supply Chain Management - GSCM) stratégia alkalmazása szükséges. Cikkükben egy, a tejipari ellátási láncra alkalmazható „zöld termék portfólió” tervezéséhez használható új modellt dolgoztak ki, melyben kiemelik, hogy egy ilyen modell elkészítésében nagy szerepe van az adatgyüjtésnek, a lánc több szereplőjétől származó adatoknak és a modell létrehozásához szükséges adatok megszerzéséhez fejlett információs rendszerekre, együttmüködésre és az információ megosztására van szükség. WU és JIA (2018) kutatásukban vállalati weboldalak, internetes hírportálok, éves jelentések és szakmai publikációk archív adatait gyüjtötték össze üzleti elemzések készítéséhez, ami szintén rámutat az információmegosztás fontosságára. COSTANTINO és szerzőtársai (2015) a rendelési és készletezési folyamatokkal kapcso- 
latban állapítják meg az információmegosztás, a partnerek közötti információáramlás fontosságát, beszállítói és értékesítési (upstream és downstream) oldalon egyaránt.

DING és szerzőtársai (2018) az információkhoz való egyszerü hozzáférést, és a megfelelő információáramlást szintén a tejipari biztonságot és minőséget megnövelő kapcsolatok közé sorolják. BOURLAKIS és szerzótársai (2014) a görög tejipari ellátási láncra vonatkozóan foglalják össze és elemzik a fenntarthatósági teljesítmény mutatókat és kiemelik a nyomonkövetési információk kulcsfontosságú élelmiszeripari szerepét. GRIMM és szerzőtársai (2014) számos szakirodalmi forrást feldolgozva foglalták össze a nyomonkövethetőség szerepét a fenntartható ellátási láncokban. Ezek az információk kulcsfontosságúak egy élelmiszerbiztonsági válság esetén annak érdekében, hogy irányítani lehessen a termékvisszahívást (DABENNE és GAY, 2011). Élelmiszerbiztonsági probléma esetében a vállalatok gyorsabb és költséghatékonyabb módon tudnak reagálni és időben vissza tudják hívni az érintett termékeket és csökkenteni tudják az ebből eredő hatásokat (FÜZESI et al., 2016; MALONI és BROWN, 2006). DING és szerzótársai (2018) a tejiparra vonatkozó kormányzati szabályozások pozitív hatásai közé sorolják az információkhoz való egyszerü hozzáférést, ami növeli a tejipari biztonságot és minőséget. A nyomon követéshez használt IKT eszközök, melyeket élelmiszerbiztonsági szabályozás miatt kötelező használni a vezetés számára is információt szolgáltat és ezek lényegesek lehetnek az anyagáramlás kisimításában és az információáramlás folytonosságának fenntartásában, így növelhetik a hatékonyságot és csökkenthetik a költségeket (FÜZESI et al., 2016).

PANT és szerzőtársai (2015) egy olyan keretrendszert mutatnak be, amely a vezetőség részére átláthatóságot, nyomonkövethetőséget és megfelelő információáramlást biztosít a tejipari ellátási láncban. TRIENEKENS és szerzőtársai (2012) az élelmiszer ellátási lánc átláthatóságának öt kritériuma közé sorolják az IKT eszközöket. PANT és szerzőtársai (2015) megállapítása, hogy az információs átláthatóság növelése olyan infrastruktúrát igényel, mely biztosítja a folyamatos információáramlást és az adatok megosztását a partnerekkel.

\section{ANYAg ÉS MódSZER - MATERIAL} AND METHODS

A cikkünkben elemzett kérdőív adatait 2017 negyedik negyedévében gyüjtötték, a válaszokat közvéleménykutató cég rögzítette. A válaszadók minden esetben a vállalatok vezetői, vagy a vezetőség egy tagja volt. A mintavételhez a Központi Statisztikai Hivatal adatait használtuk fel, a mintavétel alapja a vállalkozások NUTS-2-szintű régiós megoszlása és az alkalmazotti létszám-kategória volt. Az adatbázis 500 mezőgazdaságban és élelmiszeriparban, termelésben és feldolgozásban múködő vállalkozásra vonatkozóan tartalmaz adatokat az IKT használatával kapcsolatosan. Az adatbázisban megjelenő vállalkozások pontos tevékenységi kódjait az 1. táblázat tartalmazza.

A megkérdezett vállalkozások megoszlását a KSH Tájékoztatási adatbázisában (Gazdasági szervezetek statisztikája) szereplő teljes sokasághoz képest, létszámkategória és régió szerint az 2. táblázat tartalmazza.

A megkérdezett vállalkozások száma és megoszlása létszámkategória és régió szerint tükrözi a KSH adatbázisában közölt adatokat a kiválasztott vállalkozási tevékenységekre vonatkozóan. A mintaelemszám a teljes sokaság mintegy 3 százaléka, azonban ha a mikrovállalkozások nélkül számoljuk, akkor a KSH adatbázisban szereplő vállalkozások majdnem 12 százalékát jelentik. A mintából 28 vállalkozás tevékenységi köre tejtermelés, 10 vállalkozás pedig tejtermékek gyártásával foglalkozik.

Cikkünk fő célkitűzése annak meghatározása, hogy van-e különbség az élelmiszertermelő és az élelmiszerfeldolgozó vállalkozások, illetve külön a tejtermelő és tejfeldolgozó vállalkozások között abból a szempontból, hogy partnerkapcsolataiban hogyan értékeli az internetes megoldások fontosságát bizonyos vállalati tevékenységekhez. A kérdőív kérdése, melyet elemeztünk: „Értékelje az internetes megoldások (ingyenes felhőszolgáltatások) fontosságát a partnerkapcsolataiban". A válaszadók 5 fokozatú Likert-skálán pontozták ezeket, négy vállalati tevékenységre vonatkozóan (kommunikáció; adattárolás, adatcsere, dokumentumkészítés; logisztika; marketing). A statisztikai számításokat SPSS 23 programmal végeztük el. 
Botos, Sz. - Szilágyi, R. - VÁRAllyai, L. - Felföldi, J.

1. TÁBLÁZAT

A megkérdezett vállalkozások tevékenységi kódjai (TEÁOR)

TABLE 1

(NACE Rev.2 Codes of Respondent Enterprises)

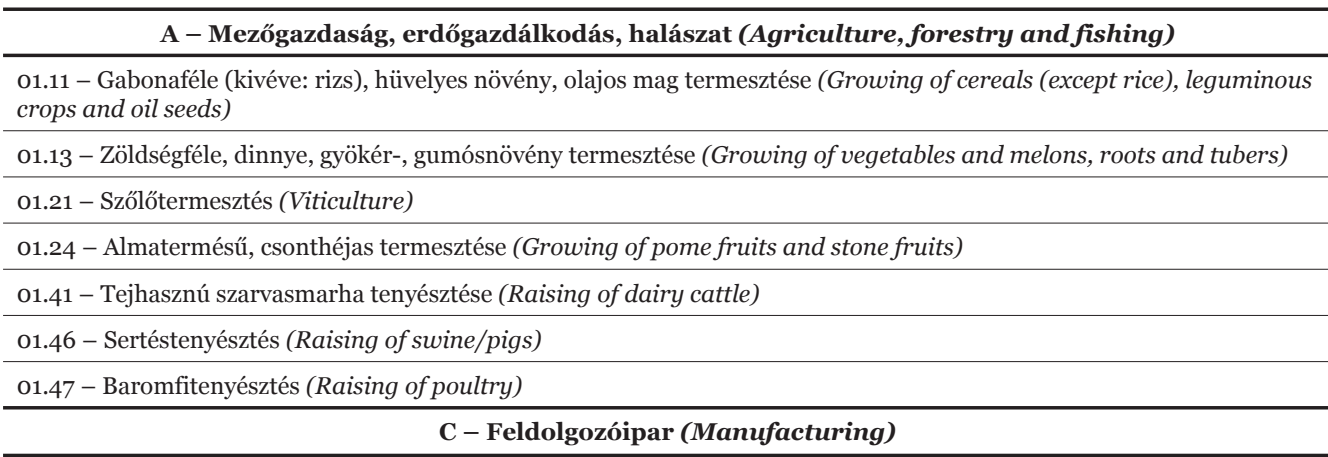

10.1 - Húsfeldolgozás, -tartósítás, húskészítmény gyártása (Processing and preserving of meat and production of meat products)

10.3 - Gyümölcs-, zöldségfeldolgozás, -tartósítás (Processing and preserving of fruit and vegetables)

10.5 - Tejfeldolgozás (Manufacture of dairy products)

10.7 - Pékáru, tésztafélék gyártása (Manufacture of bakery and farinaceous products)

2. TÁBLÁZAT

A megkérdezett vállalkozások megoszlása

(Share of Respondent Companies)

\begin{tabular}{|c|c|c|c|c|c|}
\hline $\begin{array}{l}\text { Méretkategória } \\
\text { (Size category) } \\
\text { Régió } \\
\text { (Region) }\end{array}$ & $\begin{array}{l}\text { Mikro } \\
\text { (Micro) }\end{array}$ & $\begin{array}{c}\text { Kis } \\
\text { (Small) }\end{array}$ & $\begin{array}{c}\text { Közép } \\
\text { (Medium) }\end{array}$ & $\begin{array}{c}\text { Nagy } \\
\text { (Large) }\end{array}$ & $\begin{array}{l}\text { Összesen } \\
\text { (Total) }\end{array}$ \\
\hline & \multicolumn{5}{|c|}{$\begin{array}{l}\text { Vállalkozások száma a KSH adatbázisában } \\
\text { (Number of enterprises in HCSO database) }\end{array}$} \\
\hline Közép-Magyarország & 1807 & 377 & 70 & 7 & 2261 \\
\hline Közép-Dunántúl & 1273 & 191 & 42 & 11 & 1517 \\
\hline Nyugat-Dunántúl & 1646 & 202 & 49 & 6 & 1903 \\
\hline Dél-Dunántúl & 1610 & 241 & 50 & 3 & 1904 \\
\hline Észak-Magyarország & 1465 & 168 & 47 & 2 & 1682 \\
\hline Észak-Alföld & 4423 & 346 & 95 & 7 & 4871 \\
\hline Dél-Alföld & 3276 & 393 & 98 & 17 & 3784 \\
\hline \multirow[t]{2}{*}{ Összesen (Total) } & 15500 & 1918 & 451 & 53 & 17922 \\
\hline & \multicolumn{5}{|c|}{$\begin{array}{l}\text { Válaszadó vállalkozások száma } \\
\text { (Number of enterprises surveyed) }\end{array}$} \\
\hline Közép-Magyarország & 23 & 28 & 7 & $\overline{\mathrm{o}}$ & 58 \\
\hline Közép-Dunántúl & 19 & 23 & 6 & 1 & 49 \\
\hline Nyugat-Dunántúl & 18 & 30 & 3 & 2 & 53 \\
\hline Dél-Dunántúl & 27 & 21 & 10 & o & 58 \\
\hline Észak-Magyarország & 25 & 14 & 6 & o & 45 \\
\hline Észak-Alföld & 57 & 50 & 17 & 3 & 127 \\
\hline Dél-Alföld & 40 & 47 & 21 & 2 & 110 \\
\hline Összesen (Total) & 209 & 213 & 70 & 8 & 500 \\
\hline
\end{tabular}


Első lépésben normalitás vizsgálatot végeztünk az adatokon, melynek eredménye, hogy az adatok megközelítőleg normál eloszlást mutatnak. A csúcsosság és a ferdeség vizsgálatának eredménye -1 és +1 között változott. Második lépésként homogenitás vizsgálatot végeztünk. $\mathrm{Az}$ adataink két független mintát tartalmaznak, ezért a mintaátlag összehasonlításához előzetesen a két minta szórásának hibahatáron belüli megegyezését teszteltük F-próbával. A Levene-próba általában nagy és azonos csoportméreteknél erős statisztikailag, kis méretú, eltérő elemszámú csoportoknál nem, ezért az F-próbát használtuk és a kétmintás t-próbák eredményeit közlő táblákban is ennek eredményeit tüntettük fel. Harmadik lépésben annak eldöntésére, hogy a két csoport kérdésekre adott pontszámainak átlaga között a különbség szignifikáns-e vagy sem, kétmintás t-próbát alkalmaztunk, egyenlő és nem egyenlő szórásnégyezekkel, az F-próba eredményei alapján. A Likert-skálán mért adatokat illetően van lehetőség független mintákon kétmintás t-próbát alkalmazni, egyenlő vagy nem egyenlő szórásnégyzetekkel, így ezt a tesztet alkalmaztuk a két csoport átlagértéke közötti különbség szignifikáns voltának meghatározásához (NORMAN, 2010).

A hipotézisünk az, hogy az élelmiszertermelő és az élelmiszerfeldolgozó vállalkozások, illetve ezen belül a tejtermelő és a tejfeldol- gozó vállalkozások között van kimutatható különbség az IKT használatában, illetve fontosságának megítélésében. Hipotézisünket megtartjuk, azaz szignifikánsnak tekintjük a különbséget a két csoport által a kérdésekre adott pontszámok átlaga között, ha a független t-próba eredményeként $2 \mathrm{P}<5 \%$.

\section{EREDMÉNYEK - RESUlts}

Cikkünkben a tejtermelő és tejfeldolgozó szektorban múködő vállalkozások által értékelt, az IKT használatára vonatkozó kérdéseket elemeztük. Ez jelen esetben a különböző IKT eszközök és internetes szolgáltatások fontosságának megítélését jelenti, ezen belül pedig a fejlett és az ingyenes alkalmazásokról alkotott véleményt tükrözik az eredmények. Az 1. és a 2. ábra a tejfeldolgozási és tejtermelési szektorban múködő vállalkozások által adott értékeléseket mutatja a vezetékes telefon, a mobiltelefon és az internet partnerkapcsolatokban betöltött szerepére vonatkozóan.

$\mathrm{Az}$ 1. ábrán látható, hogy a tejtermelő vállalkozások a beszállítói és a vevői kapcsolataiban a mobiltelefon használatát tartják fontosnak, de az internet is egyre fontosabb szerepet tölt be. A kormányzati szervezetekkel ezzel szemben az online ügyintézés dominál.

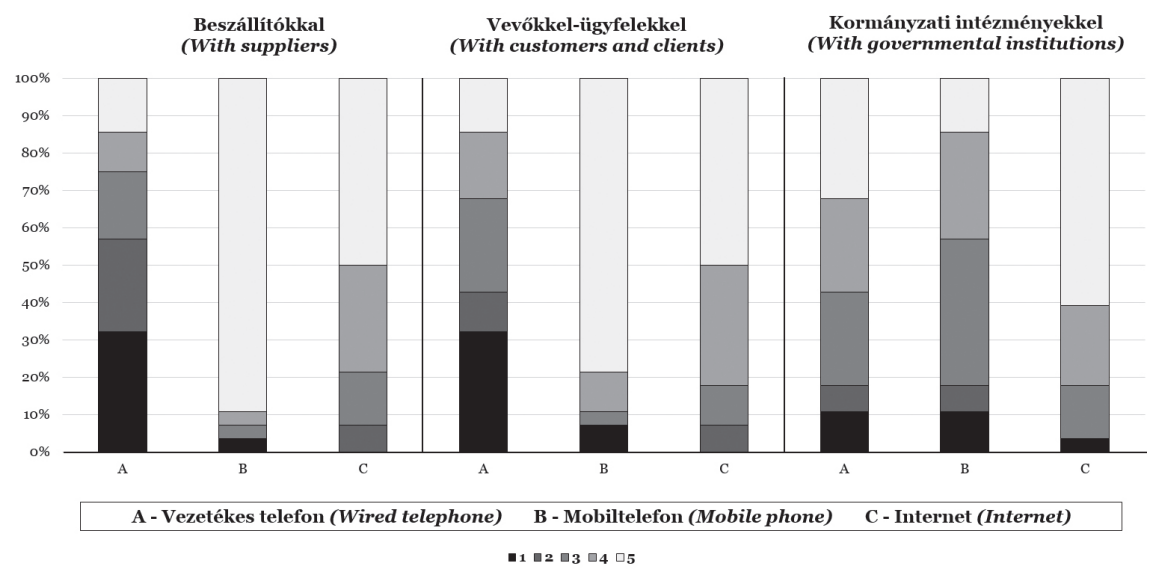

1. ÁBRA

FIG. 1

A tejtermelő vállalkozások által adott pontszámok megoszlása a kérdésre: „Értékelje a partnerkapcsolatokban használható kommunikációs eszközök fontosságát”

(Share of Scores Given by Milk Producers for the Question: "Evaluate the Importance of Communication Tools in Your Partnerships") 
A tejfeldolgozó vállalatok által ugyanerre a kérdésre adott pontszámait a 2. ábra mutatja be. Ellentétben a tejtermelő vállalkozásokkal, a vezetékes telefon fontossága esetükben már a kormányzati ügyintézésben is elenyésző szere- pet játszik. Továbbá jól látható, hogy az internetes felület fontossága a beszállítói és a vevői kapcsolatokban is a mobiltelefon fontosságával összemérhető.

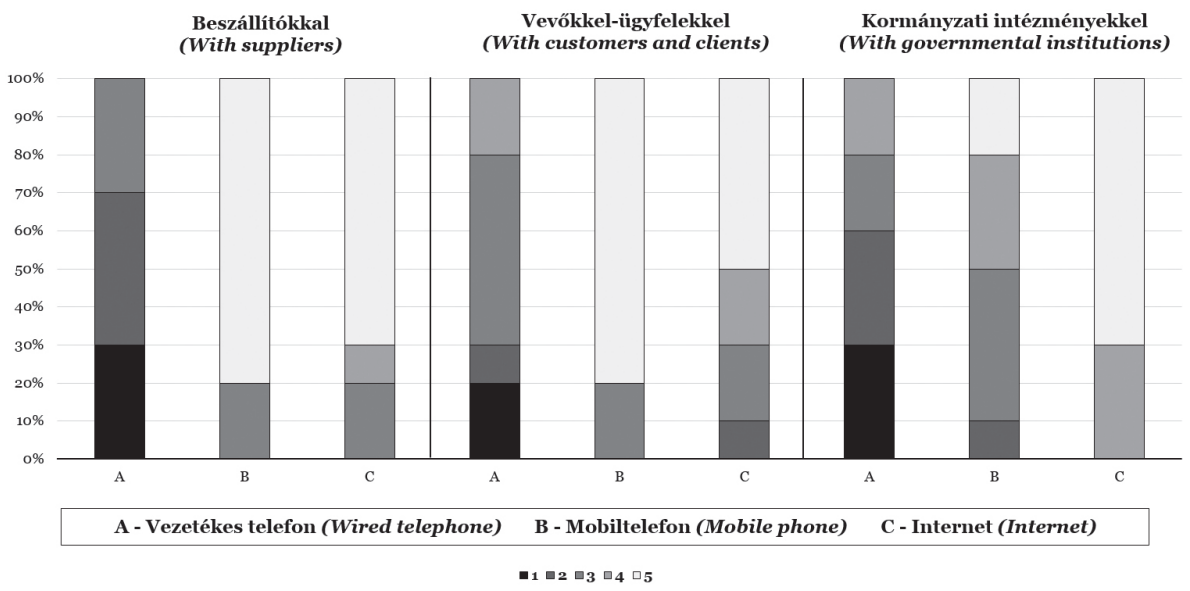

2. ÁBRA

FIG. 2

A tejfeldolgozó vállalkozások által adott pontszámok megoszlása a kérdésre: „Értékelje a partnerkapcsolatokban használható kommunikációs eszközök fontosságát"

(Share of Scores Given by Milk Processors for the Question: "Evaluate the Importance of Communication Tools in your Partnerships")

Az 1. és a 2. ábra alapján elmondható, hogy a tejfeldolgozó vállalkozások által adott pontszámok a három kommunikációs eszköz fontosságát illetően jobb átlagot mutat, mint a tejtermelő vállalkozások esetében. Mivel ebben az esetben kifejezetten a partnerkapcsolatokban használható kommunikációs formákra kérdeztünk rá, így az internet fontosságára kapott jobb eredmény nem a kötelezően használandó nyomonkövetési eszközök és információs rendszerek használatából ered, habár ezek használata adott esetben megkönnyíti és elősegíti a különböző internetes megoldások használatát is.

A 3. ábra a tejtermelő és tejfeldolgozó vállalatok által adott pontszámok megoszlását szemlélteti az ingyenes felhőszolgáltatások partnerkapcsolatokban betöltött szerepére vonatkozóan. Egyértelműen látszik, hogy mindkét szektorban dominál a magas pontozás, de a tejtermelő vállalkozások több esetben adtak alacsonyabb pontszámokat.
A tejfeldolgozás szektorban múködő vállalkozások ebben az esetben is jobb átlagot mutatnak, az ingyenes felhőszolgáltatások szerepére a termelő szektorhoz képest magasabb pontszámokat adtak mind a négy vállalati tevékenység esetében.

A 4. ábra azt mutatja, hogy a vállalkozások hogyan értékelték átlagosan az internetes megoldások használatának fontosságát a partneri kapcsolataikban a 3. ábrán már bemutatott négy vállalati tevékenység esetén. Az ábrán külön szerepel az ellátási lánc termelési, illetve feldolgozási részén múködő vállalkozások átlaga, valamint csak a tejtermelési és tejfeldolgozásban múködő vállalkozások átlaga. Az ábrán látható, hogy bár a különbségek nem nagyok, a tejtermelő és tejfeldolgozó vállalkozások által adott pontszámok átlaga valamivel magasabb, mint a teljes sokaságra számolt átlag. 

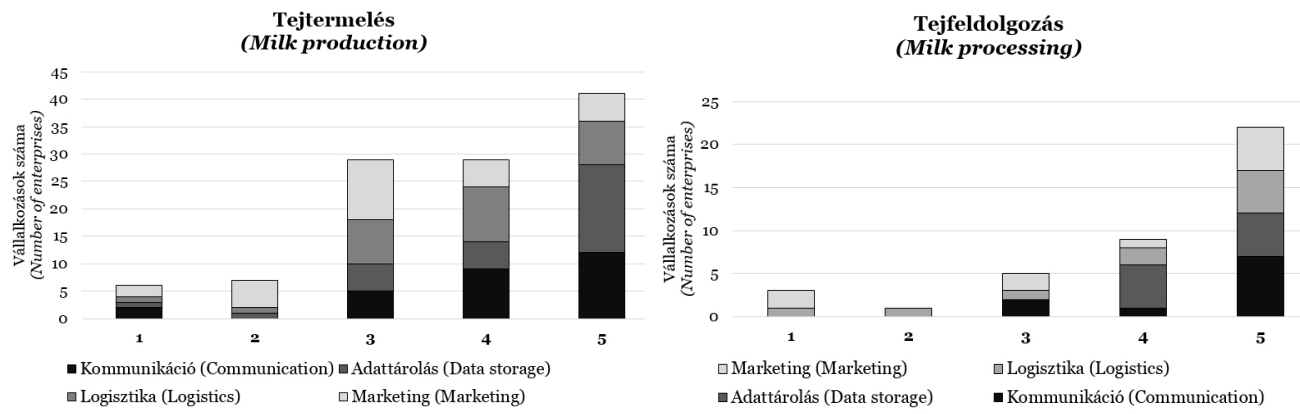

3. ÁBRA

口Adattárolás (Data storage)

FIG. 3

A tejtermelő és tejfeldolgozó vállalkozások által adott pontszámok a kérdésre: „Értékelje az ingyenes felhőszolgáltatások fontosságát a partnerkapcsolataiban”

(Share of Scores Given by Milk Producers and Processors for the Question: "Evaluate the Importance of Free Cloud Solutions in your Partnerships")

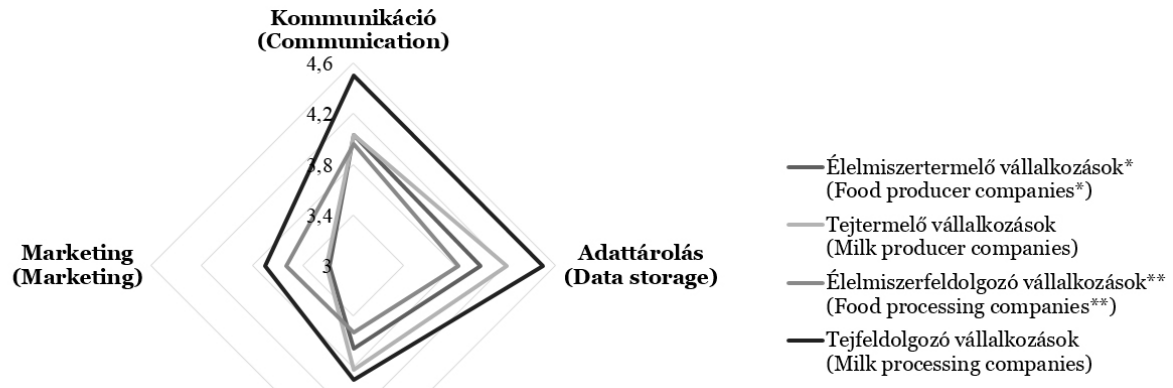

4. ÁBRA

Logisztika

(Logistics)

FIG. 4

A tejtermelő és tejfeldolgozó vállalkozások által adott pontszámok a kérdésre: „Értékelje az internetes megoldások (ingyenes felhőszolgáltatások) fontosságát a partnerkapcsolataiban" (Share of Scores Given by Milk Producers and Processors for the Question: "Evaluate the Importance of Internet-Based (Free Cloud) Solutions in your Partnerships")

*Ez a csoport tartalmazza a kérdőívre válaszoló összes élelmiszertermelő vállalkozást (1. táblázat A része) (This group contains all the food producer companies answered for the survey (Table 1 Part A))

**Ez a csoport tartalmazza a kérdőívre válaszoló összes élelmiszerfeldolgozó vállalkozást (1. táblázat C része) (This group contains all the food processing companies answered for the survey (Table 1 Part C))

Az általános elemzés eredménye alapján tovább vizsgáltuk, hogy a két szektor között tapasztalt különbség szignifikánsnak mondható-e az élelmiszertermelő és az élelmiszerfeldolgozó, valamint ezen belül a tejtermelő és tejfeldolgozó vállalatok között az előző kérdésre adott pontszámok átlagát illetően. Az első két csoport leíró statisztikájának eredményét a 3. táblázat tartalmazza. 
Az élelmiszertermelók és élelmiszerfeldolgozók pontszámának leíró statisztikája (Descriptive Statistics of the Scores Given by Food Producers and Food Processors)

\begin{tabular}{|c|c|c|c|c|c|c|}
\hline \multirow{3}{*}{ Változók (Variables) } & \multicolumn{3}{|c|}{$\begin{array}{l}\text { Élelmiszertermelők } \\
\text { (Food producers) }\end{array}$} & \multirow{2}{*}{\multicolumn{3}{|c|}{$\begin{array}{c}\text { Élelmiszerfeldolgozók } \\
\text { (Food processors) } \\
\text { Megfigyelések (Observations): } 145\end{array}$}} \\
\hline & \multicolumn{3}{|c|}{ Megfigyelések (Observations): 355} & & & \\
\hline & $\begin{array}{l}\text { Átlag } \\
\text { (Mean) }\end{array}$ & $\begin{array}{l}\text { Szórás } \\
\text { (Std. } \\
\text { Deviation) }\end{array}$ & $\begin{array}{l}\text { Standard } \\
\text { hiba } \\
\text { (Std.Error } \\
\text { Mean) }\end{array}$ & $\begin{array}{c}\text { Átlag } \\
\text { (Mean) }\end{array}$ & $\begin{array}{l}\text { Szórás } \\
\text { (Std. } \\
\text { Deviation) }\end{array}$ & $\begin{array}{l}\text { Standard } \\
\text { hiba } \\
\text { (Std.Error } \\
\text { Mean) }\end{array}$ \\
\hline $\begin{array}{l}\text { Kommunikáció } \\
\text { (Communication) }\end{array}$ & 4,03 & 1,1519 & 0,0611 & 3,96 & 1,3064 & 0,1085 \\
\hline $\begin{array}{l}\text { Adattárolás, adatcsere, } \\
\text { dokumentumkészítés } \\
\text { (Data store and exchange, } \\
\text { prepare documents) }\end{array}$ & 4,01 & 1,2050 & 0,0640 & 3,83 & 1,3506 & 0,1122 \\
\hline $\begin{array}{l}\text { Logisztika } \\
\text { (Logistics) }\end{array}$ & 3,66 & 1,2530 & 0,0665 & 3,52 & 1,4957 & 0,1242 \\
\hline $\begin{array}{l}\text { Marketing } \\
\text { (Marketing) }\end{array}$ & 3,19 & 1,3492 & 0,0716 & 3,53 & 1,5141 & 0,1257 \\
\hline
\end{tabular}

A négy vállalati tevékenységhez használható internetes megoldások fontosságára adott pontszámokon lefuttatott független kétmintás t-próba eredményét a 4. táblázat tartalmazza.
TABLE 3
Élelmiszerfeldolgozók (Food processors)

\section{TÁBLÁZAT}

A próbát az élelmiszertermelők és az élelmiszerfeldolgozók teljes, 500-as elemszámú mintáján futtattuk le.

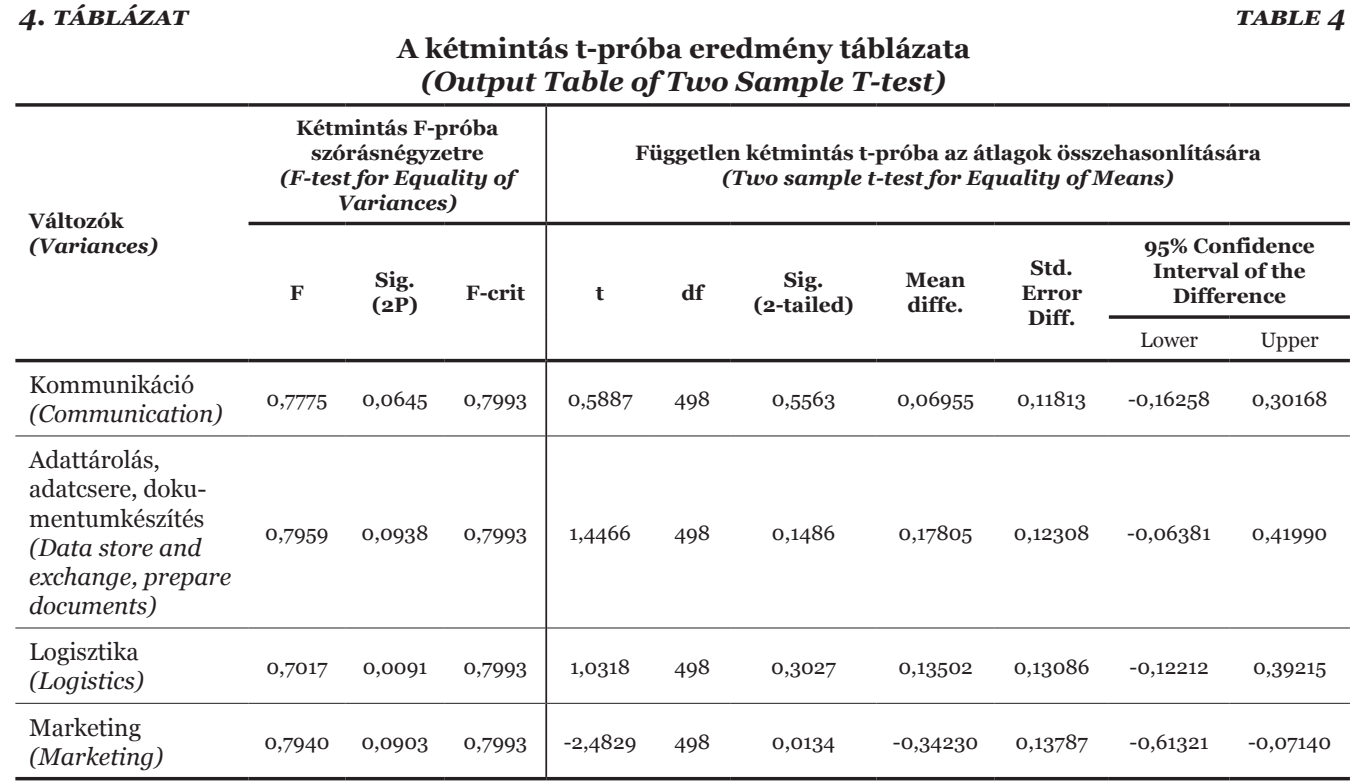

A kétmintás t-próba eredményének táblázatából jól látszik, hogy az élelmiszertermelő és az élelmiszerfeldolgozó vállalatok értékelése között csak a marketingtevékenység fontosságára adott pontszámok átlagában van szig- nifikáns különbség (Sig. (2-tailed)=0,0134). A t-érték -2,4829, azaz az élelmiszerfeldolgozók kérdésre adott pontszámának átlaga magasabb, mint az élelmiszertermelő vállalkozások átlaga. A pontszámok átlagában a legkisebb 
eltérés a kommunikációhoz használt IKT eszközök fontossága esetében van.

A tejiparra szúkített adatok esetében szin- tén elvégeztük ezt az elemzést, ennek leíró statisztáját az 5. táblázat tartalmazza.

5. TÁBLÁZAT

A tejtermelő és a tejfeldolgozó vállalkozások pontszámának leíró statisztikája

TABLE 5 (Descriptive Statistics of the Scores Given by Milk Producers and Milk Processors)

\begin{tabular}{|c|c|c|c|c|c|c|}
\hline \multirow[b]{2}{*}{ Változók (Variables) } & \multicolumn{3}{|c|}{$\begin{array}{c}\text { Tejtermelók (Milk producers) } \\
\text { Megfigyelések (Observations): } 28\end{array}$} & \multicolumn{3}{|c|}{$\begin{array}{l}\text { Tejfeldolgozók (Milk processors) } \\
\text { Megfigyelések (Observations): } 10\end{array}$} \\
\hline & $\begin{array}{l}\text { Átlag } \\
\text { (Mean) }\end{array}$ & $\begin{array}{c}\text { Szórás } \\
\text { (Std. } \\
\text { Deviation) }\end{array}$ & $\begin{array}{c}\text { Standard } \\
\text { hiba } \\
\text { (Std.Error } \\
\text { Mean) }\end{array}$ & $\begin{array}{c}\text { Átlag } \\
\text { (Mean) }\end{array}$ & $\begin{array}{c}\text { Szórás } \\
\text { (Std. } \\
\text { Deviation) }\end{array}$ & $\begin{array}{c}\text { Standard } \\
\text { hiba } \\
\text { (Std.Error } \\
\text { Mean) }\end{array}$ \\
\hline $\begin{array}{l}\text { Kommunikáció } \\
\text { (Communication) }\end{array}$ & 4,04 & 1,1380 & 0,2151 & 4,50 & 0,8498 & 0,2687 \\
\hline $\begin{array}{l}\text { Adattárolás, adatcsere, } \\
\text { dokumentumkészítés } \\
\text { (Data store and exchange, } \\
\text { prepare documents) }\end{array}$ & 4,21 & 1,1007 & 0,2080 & 4,50 & 0,5270 & 0,1667 \\
\hline $\begin{array}{l}\text { Logisztika } \\
\text { (Logistics) }\end{array}$ & 3,82 & 1,0203 & 0,1928 & 3,90 & 1,4491 & 0,4583 \\
\hline $\begin{array}{l}\text { Marketing } \\
\text { (Marketing) }\end{array}$ & 3,21 & 1,1661 & 0,2204 & 3,70 & 1,6364 & 0,5175 \\
\hline
\end{tabular}

A leíró statisztika alapján két esetben térnek el nagyobb mértékben az átlagértékek. Az IKT eszközök megítélése a kommunikációs és a marketingtevékenységekben pozitívabb a tejfeldolgozók esetében. Annak megállapítá-

6. TÁBLÁZAT sához, hogy ez a különbség szignifikáns-e vagy sem, szintén kétmintás t-próbát alkalmaztunk a két csoport által adott pontszámokon, ennek eredményét a 6. táblázat tartalmazza.

\begin{tabular}{|c|c|c|c|c|c|c|c|c|c|c|}
\hline \multicolumn{11}{|l|}{ 6. TÁBLÁZAT } \\
\hline \multirow{3}{*}{$\begin{array}{l}\text { Változók } \\
\text { (Variances) }\end{array}$} & \multicolumn{3}{|c|}{$\begin{array}{l}\text { Kétmintás F-próba } \\
\text { szórásnégyzetre } \\
\text { (F-test for Equality of } \\
\text { Variances) }\end{array}$} & \multicolumn{7}{|c|}{$\begin{array}{l}\text { Független kétmintás t-próba az átlagok összehasonlítására } \\
\text { (Two sample t-test for Equality of Means) }\end{array}$} \\
\hline & \multirow[t]{2}{*}{$\mathbf{F}$} & \multirow[t]{2}{*}{$\begin{array}{l}\text { Sig. } \\
(2 P)\end{array}$} & \multirow[t]{2}{*}{ F-crit } & \multirow[t]{2}{*}{$\mathbf{t}$} & \multirow[t]{2}{*}{ df } & \multirow[t]{2}{*}{$\begin{array}{c}\text { Sig. } \\
\text { (2-tailed) }\end{array}$} & \multirow[t]{2}{*}{$\begin{array}{l}\text { Mean } \\
\text { diffe. }\end{array}$} & \multirow{2}{*}{$\begin{array}{l}\text { Std. } \\
\text { Error } \\
\text { Diff. }\end{array}$} & \multicolumn{2}{|c|}{$\begin{array}{l}\text { 95\% Confidence } \\
\text { Interval of the } \\
\text { Difference }\end{array}$} \\
\hline & & & & & & & & & Lower & Upper \\
\hline $\begin{array}{l}\text { Kommunikáció } \\
\text { (Communication) }\end{array}$ & 1,7930 & 0,3622 & 2,8801 & $-1,1743$ & 36 & 0,2480 & $-0,4643$ & 0,39537 & $-1,26609$ & 0,33752 \\
\hline $\begin{array}{l}\text { Adattárolás, } \\
\text { adatcsere, doku- } \\
\text { mentumkészítés } \\
\text { (Data store and } \\
\text { exchange, prepare } \\
\text { documents) }\end{array}$ & 4,3619 & 0,0257 & 2,8801 & $-1,0719$ & 32,6 & 0,2915 & $-0,2857$ & 0,36435 & $-1,02790$ & 0,45647 \\
\hline $\begin{array}{l}\text { Logisztika } \\
\text { (Logistics) }\end{array}$ & 0,4957 & 0,1536 & 0,4444 & $-0,1866$ & 36 & 0,8530 & $-0,0786$ & 0,42096 & $-0,93228$ & 0,77514 \\
\hline $\begin{array}{l}\text { Marketing } \\
\text { (Marketing) }\end{array}$ & 0,5078 & 0,1678 & 0,4444 & $-1,0144$ & 36 & 0,3172 & $-0,4857$ & 0,47881 & $-1,45674$ & 0,48531 \\
\hline
\end{tabular}


Az elemzés alapján nincs szignifikáns különbség a tejtermelő és a tejfeldolgozó vállalatok által adott pontszámok átlaga között, bár a fentebb említett két eltérés mindenképpen jelzi, hogy az ellátási lánc két különböző pontján múködő vállalkozások eltérő mértékben tartják fontosnak az IKT eszközök használatát. A tejszektorra vonatkozóan az átlagok alapján az IKT használatának fontossága a marketingtevékenységek esetében a legalacsonyabb. Ehhez kapcsolódóan FEHÉR és SZAKÁLY (2018) cikkükben a magyarországi tejszektor online marketing lehetőségeit elemezték és megállapították, hogy ebben a szektorban az internetes jelenlét minősége (honlap megléte, weboldalon található információk frissítése, weboldalak tartalmi és formai jellemzői) alacsony színvonalú, és további kutatásokat tartanak fontosnak a helyzet javítása érdekében.

\section{KöVETKEZTETÉSEK - CONCLUSIONS}

Az eredmények alapján elmondható, hogy nincs egyértelmű és nagy különbség a termelő és a feldolgozó szektor között. A független kétmintás t-próba csak egy változó (IKT értékelése marketingtevékenységekhez) esetében mutatott szignifikáns különbséget az élelmiszerfeldolgozó vállalkozások javára, de általánosságban csak kis mértékben különböznek az átlagok, melyeket a különböző IKT megoldások használatának fontosságára adtak a megkérdezett vállalkozások vezetôi. A tejfeldolgozásban múködő vállalatok pontszámának átlaga mind a négy esetben kedvezőbben alakult a teljes élelmiszertermelő- és feldolgozó vállalkozások átlagához képest. Véleményünk szerint ez annak tudható be, hogy a tejiparban kötelezően használandó IKT eszközök, nyomonkövetési és információs rendszerek elősegítik a nem kötelező, de hasznos és a vállalkozási tevékenységeket (kommunikáció, adatcsere, logisztika, stb.) megkönnyítő IKT eszközök használatát is. Ha csak a tejtermelő és tejfeldolgozó vállalkozások IKT használatának összehasonlító elemzését nézzük, akkor elmondható, hogy a tejfeldolgozó vállalkozások általánosságban többre értékelik az IKT megoldásokat, a pontszámok átlaga magasabb. Azonban ez az elté- rés statisztikailag nem igazolható, a t-próba eredménye szerint ez a különbség nem szignifikánsan magasabb a tejtermelő vállalatok által adott pontszámokhoz képest. Mindenképpen fontosnak tartjuk azonban megemlíteni, hogy a feldolgozó szektorban az értékesítési oldal már a fogyasztókhoz is kapcsolódik, ezért az egyes vállalati tevékenységekhez használt, illetve használható internetes megoldások valószínüleg fontosabb szereppel bírnak. Ennek ellenére lényeges lenne a tejtermelők IKT használatát is magasabb szintre emelni, hiszen az élelmiszerellátási lánc egészét vizsgálva egyre inkább komplex partneri kapcsolatokban és vállalati tevékenységekben kell gondolkodni és ez megköveteli az IKT eszközök használatát, ezen túlmenően pedig a költségkímélő és biztonságos internetes megoldásoknak pozitív hozadéka lehet mind pénzügyi, mind fenntarthatósági szempontból. Korábbi cikkünkben (BOTOS et al., 2018) ugyanerre az adatbázisra, a vállalati létszámkategóriák között lefuttatott t-próbák eredménye szerint több esetben volt különbség a csoportok között, ezért további elemzéseket végzünk annak meghatározására, hogy milyen tényezők befolyásolhatják a vállalati IKT használatát, az IKT megoldások megítélését. A kutatást fontosnak tartjuk az IKT fejlesztését célzó beruházások és célzott fejlesztési projektek megvalósítása előtti döntéshozatal megkönnyítése érdekében.

\section{5. ÖSSZEFOGLALÁS - SUMMARY}

A tejtermelés- és feldolgozás Magyarország egyik legfontosabb agrár-élelmiszeripari szektora, 2016-ban 741 tejtermelő és 80 tejfeldolgozó vállalkozás múködött. A fejlett információs rendszereknek köszönhetően a múködésükről és a teljesítményükről elérhető adatok köre tágabb, pontosabb és megbízhatóbb, ami nagyon fontos, hiszen ezek elemzése kulcsfontosságú a szektorok közötti és a szektoron belüli helyzetértékeléshez. Ezek az adatok fontosak a különböző szektorok teljesítményének nyomon követésében és értékelésében. A Központi Statisztikai Hivatal (KSH) adatbázisai multidimenzionális formában is elérhetőek, míg az EMIS adatbázisából pénzügyi adatok és egyéb kiegészítő információk tölthetőek le a tejszek- 
torban múködő vállalkozások több mint feléről. Kiegészítő adatbázisként az Alkalmazott Informatika és Logisztika Intézet egy kérdőívet készített az agrár-élelmiszeripari ellátási láncban múködő vállalkozások (termelés és feldolgozás) IKT (Információs és Kommunikációs Technológia) használati jellemzőinek felméréséhez. A kérdőívet 2017 utolsó negyedévében, közvéleménykutató cég közremúködésével töltötték ki vállalatok vezetői, vagy vezetőségi tagjai. A vállalkozások kiválasztása irányított mintavétellel történt a KSH adatbázisa alapján. A mintavétel alapja a vállalatok számának megoszlása vállalati méret és a NUTS-2-szintü régió szerint. Az adatbázis 500 mezőgazdasági és élelmiszeripari vállalkozásról tartalmaz adatokat (a vállalkozások közül 355 a termelési, 145 pedig a feldolgozási szektorban múködik). A mintaelemszámból 38 tejszektorban múködő vállalkozás (ebből 28 tejtermelő és 10 tejfeldolgozó vállalkozás). Cikkünk fó célkitüzése annak meghatározása, hogy van-e különbség az élelmiszertermelő és az élelmiszerfeldolgozó vállalkozások, illetve külön a tejtermelő és tejfeldolgozó vállalkozások között abból a szempontból, hogy hogyan értékelik az IKT eszközök fontosságát a partnerkapcsolatokban és az internetes megoldások fontosságát bizonyos vállalati tevékenységekhez. A válaszadók 5 fokozatú Likert-skálán értékelték ezeket, négy vállalati tevékenységre vonatkozóan (kommunikáció; adattárolás, adatcsere, dokumentumkészítés; logisztika; marketing). A különbségek meghatározásához független kétmintás t-próbát alkalmaztunk. Eredményeink szerint szignifikáns különbség csak a teljes mintára számítva, az élelmiszertermelők és élelmiszerfeldolgozók között van, az IKT eszközök marketingcélú használatának értékelésében. Az élelmiszerfeldolgozók kérdésre adott pontszámának átlaga szignifikánsan magasabb (Sig. (2-tailed)=0,0134) és t-érték -2,4829). A tejtermelők és a tejfeldolgozók között szignifikáns különbség nincs, azonban az IKT eszközök használatának fontosságára adott pontszámok átlaga mind a négy üzleti tevékenységre vonatkozóan magasabb a tejfeldolgozó szektor esetében.

\section{IRODALOMJEGYZÉK - REFERENCES}

Bian, W. - Shang, J. - Zhang, J. (2016): Two-Way Information Sharing Under Supply Chain Competition. International Journal of Production Economics. 178 82-94. https://doi.org/10.1016/j. ijpe.2016.04.025

Botos, Sz. - Várallyai, L. - Szilágyi, R. - Felföldi, J. (2018): Relation Between Corporate Size and ICT Usage in AgroFood SMEs. Journal of EcoAgriTourism. 14 (1) $63-73$.

Bourlakis, M. - Maglaras, G. - Gallear, D. - Fotopoulos, C. (2014): Examining Sustainability Performance in the Supply Chain: The Case of the Greek Dairy Sector. Industrial Marketing Management. 43 (1) 56-66. https://doi.org/10.1016/j. indmarman.2013.08.002

Costantino, F. - Di Gravio, G. - Shaban, A. - Tronci, M. (2015): The Impact of Information Sharing on Ordering Policies to Improve Supply Chain Performances. Computer \& Industrial Engineering. 82 127-142. https://doi.org/10.1016/j. cie.2015.01.024

Dabenne, F. - Gay, P. (2011): Food Traceability Systems: Performance Evaluation and Optimization. Computers and Electronics in Agriculture. 75 (1) 139-146. https://doi.org/10.1016/j. compag.2010.10.009

Ding, H. - Fu, Y. - Zheng, L. - Yan, Z. (2018): Determinants of the Competitive Advantage of Dairy Supply Chains: Evidence from the Chinese Dairy Industry. International Journal of Production Economics. In Press. https://doi. org/10.1016/j.ijpe.2018.02.013

Dominguez, R. - Cannella, S. - BarbosaPóvoa, A. P. - Framinan, J. M. (2018): Information Sharing in Supply Chains with Heterogeneous Retailers. Omega. 79 116-132. https://doi.org/10.1016/j. omega.2017.08.005 
Fawcett, S. E. - Wallin, C. - Allred, C. - Fawcett, A. M. - Magnan, G. M. (2011): Information Technology as an Enabler of Supply Chain Collaboration: A Dynamic-Capabilities Perspective. Journal of Supply Chain Management. 47 (1) $38-59$.

Fehér, A. - Szakály, Z. (2018): A hazai tejszektor online marketing lehetőségei. Tejgazdaság. 75 (1) 55-65.

Füzesi, I. - Lengyel, P. - Csobán, K. - Szilágyi, R. (2016): Analysis of ICT Support in Hungarian Meat Sector. Agrárinformatika / Journal of Agricultural Informatics. 72 60-69. https://doi.org/10.17700/jai.2016.7.2.306

Gouvea, R. - Kapelianis, D. - Kassicieh, S. (2018): Assessing the Nexus of Sustainability and Information \& Communications Technology. Technological Forecasting \& Social Change. $130 \quad 39-44 . \quad$ https://doi. org/10.1016/j.techfore.2017.07.023

Grimm, J. H. - Hofstetter, J. S. - Sarkis, J. (2014): Critical Factors for SubSupplier Management: A Sustainable Food Supply Chains Perspective. International Journal of Production Economics. 152 159-173. https://doi.org/10.1016/j. ijpe.2013.12.011

Kirilova, E. G. - Vaklieva-Bancheva, N. Gr. (2017): Environmentally Friendly Management of Dairy Supply Chain for Designing a Green Products' Portfolio. Journal of Cleaner Production. 167 493-504. https://doi.org/10.1016/j. jclepro.2017.08.188

Maloni, M. J. - Brown, M. E. (2006): Corporate Social Responsibility in the Supply Chain: An Application in the Food Industry. Journal of Business Ethics. 68 (1) 35-52. https://doi.org/10.1007/ s10551-006-9038-o

Norman, G. (2010): Likert Scales, Levels of Measurement and the „Laws” of Statistics. Advances in Health Sciences Education. 15 (5) 625-632. https://doi.org/10.1007/ s10459-010-9222-y
Pant, R. R. - Prakash, G. - Farooquie, J. A. (2015): A Framework for Traceability and Transparency in the Dairy Supply Chain Networks. Procedia - Social and Behavioral Sciences. 189 385-394. https://doi.org/10.1016/j. sbspro.2015.03.235

Santis, P. - Albuquerque, A. - Lizarelli, F. (2016): Do Sustainable Companies Have a Better Financial Performance? A Study on Brazilian Public Companies. Journal of Cleaner Production. 133 735-745. https://doi.org/10.1016/j. jclepro.2016.05.180

Teunter, R. H. - Babai, M. Z. - Bokhorst, J. A. C. - Syntetos, A. A. (2018): Revisiting the Value of Information Sharing in Two-Stage Supply Chains. European Journal of Operational Reserarch. 270 1044-1052. https://doi. org/10.1016/j.ejor.2018.04.040

Trienekens, J. H. - Wognum, P. M. Beulens, A. J. - van der Vorst, J. G. (2012): Transparency in Complex Dynamic Food Supply Chains. Advanced Engineering Informatics. 26 (1) 55-65. https://doi.org/10.1016/j.aei.2011.07.007

Vachon, S. - Klassen, R. D. (2006): Extending Green Practices Across the Supply Chain: The Impact of Upstream and Downstream Integragion. International Journal of Operations \& Production Management. 26 (7) 795-821. https:// doi.org/10.1108/01443570610672248

Viet, N. Q. - Behdani, B. - Bloemhof, J. (2018): The Value of Information in Supply Chain Decisions: A Review of the Literature and Research Agenda. Computers \& Industrial Engineering. 120 68-82. https://doi.org/10.1016/j. cie.2018.04.034

Wu, Z. - Jia, F. (2018): Toward a Theory of Supply Chain Fields - Understanding the Institutional Process of Supply Chain Localization. Journal of Operations Management. 58-59 27-41. https://doi. org/10.1016/j.jom.2018.03.002 
Zhou, H. - Shou, Y. - Zhai, X. - Li, L. - Wood, C. - Wu, X. (2014): Supply Chain Practice and Information Quality: A Supply Chain Strategy Study. International Journal of Production Economics. 147 624-633. https://doi.org/10.1016/j. ijpe.2013.08.025

\section{JEGYZETEK $*$ NOTES}

